\title{
OPPORTUNITIES TO REVITALISE RURAL TOURISM THROUGH THE OPERATION OF AGRARIAN COOPERATIVES
}

\author{
Filip Đokovićn ${ }^{1}$ Radovan Pejanović2 ${ }^{2}$ Miloš Mojsilović3 \\ Jelena Đorđević Boljanović ${ }^{4}$, Katarina Plećićc
}

\section{Summary}

Agrarian cooperatives are still in a period of transition. Practice shows that it is necessary to reconsider the business activities performed in the sector. Under the 2015 Cooperatives Act, rural tourism was recognised as a business activity, but the legal move has had no practical implications. In order to identify opportunities for the revitalisation of rural tourism, a study has been carried out based on interviews with the general managers of agrarian cooperatives. Their views have been analysed to gauge their awareness of the effects of rural tourism on rural areas arising from the operation of cooperatives, and the potential of human resources to implement the consequent organisational changes. In addition, the potential of agrarian cooperatives has been explored in the context of external surroundings. The results of the research have shown that the general managers view positively the revitalisation of rural tourism as part of the operation of the cooperatives, and that they are aware of the favourable impacts of tourism on rural areas, but that incompetence of the staff in the cooperatives has been a main obstacle to such a development.

Key words: agrarian cooperatives, rural tourism, general managers of cooperatives, revitalisation.

JEL: Q13, Q19, Z32.

1 Fillip Đoković Ph.D., Assistant Professor, Singidunum University, Faculty of Health, Legal and Business Studies, Železnička Street no. 5, Phone: +381 14292 610, E-mail: fdjokovic@singidunum.ac.rs

2 Radovan Pejanović Ph.D., Full Professor, University of Novi Sad, Agricultural Faculty, Dositeja Obradovica Square no. 8, 21000 Novi Sad, Phone: +381 216350 622, E-mail: pejanovic@uns.ac.rs

3 Miloš Mojsilović M.A., Ipsos Strategic Marketing, Gavrila Principa Street No. 8, Phone: +381 11 3284 075, E-mail: mojsilovic.milos@gmail.com

4 Jelena Đorđević Boljanović Ph.D., Associate Professor, Singidunum University, Faculty of Business, Kumodraška Street no. 261a, Phone: +381 113094 094, E-mail: jboljanovic@singidunum.ac.rs

5 Katarina Plećić M.A., Singidunum University, Faculty of Health, Legal and Business Studies, Železnička Street no. 5, Phone: +381 14292 610, E-mail: kplecic@singidunum.ac.rs

EP 2017 (64) 3 (1115-1132) 


\section{Introduction}

Rural development in high-income countries largely depends on cooperatives. The prosperity of rural communities hinges on a well-organised system within the agrarian cooperative sector. There is always a straightforward strategic dimension to development in a modern business environment, which is why business policies need to be harmonised with the principles of sustainable development.

Agrarian cooperatives, the area of focus in this paper, are the organisations that rest on economic as well as social and cultural values. The economic cornerstone of agrarian cooperatives suggests an entrepreneurial component, a set of actions guided by the sound market principles. (Pejanović, Njegovan, 2011) The social and cultural fundamentals uphold tradition, and support the family as the basic unit of society.

Aside from the agrarian cooperatives, the economic entities that make up the backbone of agricultural growth in Serbia include agricultural companies and individual farms (Njegovan, Pejanović, 2009; Pejanović, 2005). In terms of organisation, an agricultural company does not differ from any other, and can build ties with any business entity.

The interpretation of the basic notion behind the agrarian cooperative is rather complex, because the survival of a cooperative doesn't depend exclusively on the number of employees and the number of collective members. (Cai et al, 2016; Ziran et al, 2015). The key concerns arise from the sustainability of a connection between household owners and the collective. As things stand right now, the existing organisational and market aspects slow down the growth and development of cooperatives, requiring their repositioning in the stakeholder community, which is the driving force behind rural development. (Pejanović et al, 2013; Richards, Manfredo, 2003).

In the era of neoliberalism, the existing framework within which business policies have been created fails to produce desired results. Serbia's agrarian cooperatives are rather a consequence of the existing socio-economic system than a stable pillar of national economic growth. On the other hand, agrarian cooperatives in the European Union (EU) generate value, contributing to the economic development of member states as an integral part of a system composed of research institutions, the public and private sectors.

A modern business environment is exposed to complex and radical changes, creating a sense of urgency for organisations to reconsider repeatedly their own resources, goals and strategic guidelines. (Đoković, Kulović 2013) In order to make available the optimal use of the capacity of an organization, resources need to be reallocated as to unveil new ways to adapt to the market. In the context of agrarian cooperatives, the existing activities in their business portfolio do not add sufficient value, and have failed to create a business result. The paper is proceeding from the point that agrarian cooperatives in a process of transition should involve tourism as the business sector allowing them to improve their performance more efficiently and effectively, and to create a competitive advantage. 


\section{Theoretical Framework}

A cooperative is a voluntary organisation of individual producers and consumers designed to improve the quality of working conditions. (Pejanović, Njegovan 2011). The purpose of this type of organisation is to curb the fragmentation of agricultural land into small individual farms, with an emphasis on the equality of all participants in the cooperative, whose solidarity supports overall growth and developments.

The survival and development of rural areas rest on cooperatives. Hence the dominance of the economic purpose in building a collective. (Vučković, 1967).The economic principle pertains to market orientation, meaning that the cooperatives need to operate by the principles of productivity, liquidity and solvency. (Đekić, 2005)

The key reason for this type of association is to boost the competitiveness of rural areas and, by extension, individual producers. Without institutional support, that of a cooperative in this case, the individual agricultural producer faces very poor prospects, being exposed to numerous financial and technological risks. The aggregation has many advantages, including the lower cost of equipment, access to technology, education, training and personal development. (Njegovan, 2011; Krstić, 2002; Harris, Fulton 1999; Mihailović, 1998)

Having in mind the modern practice of cooperative action, and a large number of authors exploring the phenomenon of cooperatives, a consensus on the diversification of activities involving a cooperative system seems to be a distant prospect. (Marković, 2013; Pejčić, 2011; Maričić, 2006, Mihailović et al., 2005).

There are different forms of cooperative organisation. Depending on the purpose, cooperatives may be owned by producers, consumers and borrowers. (Pejanović, Njegovan 2011). The most common types are producers cooperatives, common facility cooperatives, cooperative banks and agricultural cooperatives. The purpose of producers cooperatives is to reduce price oscillations, contributing to a more efficient price policy and effective profit management for the members of a cooperative. Cooperative banking revolves around cooperative saving banks, providing loans for the members of cooperatives. Common facility cooperatives allow for the joint use of equipment, allowing for considerable savings in procurement and maintenance. The paper has explored agrarian cooperatives composed of individual farmers, focused on agricultural production and relevant agricultural processes.

The 2015 report Cooperatives Europe Key Figuresanalysed the key cooperative sectors and subsectors. The report included a large number of states and, unfortunately, Serbia is not one of them. Table 1 shows the shares in the total cooperative sector of cooperatives, members and employees of cooperatives, and the annual turnover of all subsectors covered by the report. 
Table 1. Cooperative subsectors, share in the total cooperative sector

\begin{tabular}{|l|c|c|c|c|}
\hline \multicolumn{1}{|c|}{ Subsector } & $\begin{array}{c}\text { Cooperative } \\
\text { Enterprises }\end{array}$ & Members & Employees & $\begin{array}{c}\text { Annual } \\
\text { Turnover }\end{array}$ \\
\hline Agriculture & $30.36 \%$ & $6.93 \%$ & $14.16 \%$ & $39.34 \%$ \\
\hline Banking & $2.48 \%$ & $43.63 \%$ & $18.18 \%$ & - \\
\hline Consumption & $6.82 \%$ & $26.99 \%$ & $12.97 \%$ & $11.63 \%$ \\
\hline Housing & $22.19 \%$ & $8.80 \%$ & $2.29 \%$ & $2.51 \%$ \\
\hline $\begin{array}{l}\text { Industry \& } \\
\text { Services }\end{array}$ & $36.60 \%$ & $2.03 \%$ & $27.53 \%$ & $9.65 \%$ \\
\hline Insurance & $0.01 \%$ & $12 \%$ & $0.83 \%$ & $6.69 \%$ \\
\hline Health Care & $0.45 \%$ & $0 \%$ & $0.06 \%$ & $0.09 \%$ \\
\hline Renewable Energy & $0.74 \%$ & $0.22 \%$ & $0.02 \%$ & $0.11 \%$ \\
\hline Retail \& Wholesale & $0.35 \%$ & $0.06 \%$ & $23.95 \%$ & $29.97 \%$ \\
\hline
\end{tabular}

Source: Cooperatives Europe Key Figures, 2015.

The share of the subsector of agriculture in the total number of cooperative enterprises is quite considerable $-30.36 \%$, but the members $(6.93 \%)$ and employees $(14.16 \%)$ of cooperatives have lower shares. The annual turnover indicates a rather high share of agriculture in the total turnover (39.34\%).

Under the 2015 Serbian Cooperatives Act, agrarian or farmer cooperatives serve different purposes, creating a specific business activity - supply, processing or services. The supply function is the basic one, as it provides cooperative members with raw materials and equipment necessary for agricultural production. The processing function serves the purpose of launching and carrying out a series of activities to make an agricultural product commercial, including the takeovers and buyoffs, processing and advertising the product and the cooperative as a whole.

The service function ties in with the previous two, paving the way to a successful trade in goods and services the cooperative and its members can offer. Special activities within the service function, which the paper deals with, involve services to the farmer households that have decided to add rural tourism to their regular activities.

In the context of agrarian cooperatives, rural tourism deserves more coverage in professional literature. In other words, the existing research has failed to explore the role of the rural tourism in the agrarian collective community.

\section{The Value Chain in an Agrarian Cooperative}

Pursuant to the national Cooperatives Act, agrarian cooperatives are market oriented enterprises, which means that the survival of an agrarian cooperative as an enterprise is made conditional on creating and maintaining value for all stakeholders. The so called "value chain" concept has been used to present a complete set of activities an agrarian cooperative performs. The purpose of the value chain is to identify those creating value and justifying the existence and survival of the enterprise. (Porter, 1998). 
The concept of value chains has a broad spectre of applications in tourism, involving tourist destinations, hotel enterprises and tour operators (Mwesiumo, Halpern, 2016; Yilmaz, Bititci, 2006).

The key activities involved in the agrarian cooperative's value chain are primary and support activities. The primary activities refer to the production processes, delivery operations, services and the presentation of a spot where the income of an agrarian cooperative is created, implying inbound logistics, production, outbound logistics, marketing and sales.

Inbound logistics include arranging storage for production materials, takeovers and buyoffs of goods and raw materials from the cooperatives. The production process involves the conversion of raw materials into a final production. Marketing and sales are to sell a product made by a member of the cooperative, or the cooperative, including promotion, sales operations and a price policy. Finally, the development of rural tourism and education are attached to the previous processes, creating additional value for stakeholders, which in turn defines long-term directions of development for agrarian collectives as enterprises.

Infrastructure, human resource management (HRM) and the development of technology represent cost-generating support activities. The infrastructure behind an agrarian cooperative consists of activities related to the management of material assets, finance, accounting, legal affairs and fiscal liabilities, while the human resources constitute a support activity managing the listed infrastructure.

Procurement is a very important segment of the value chain, which largely affects the total expenditure of an agrarian cooperative. Procurement includes the acquisition of production materials, energy, parts and accessories for agricultural machinery, etc. The development of technology is viewed against a new setting within which the processes included in the primary activities will develop more effectively and efficiently. The results of a value chain is a profit generated after the cost of the primary activities has been covered.

The national legislation allows agrarian cooperatives to perform tourist activities, but the question is if they are prepared to launch and carry out the activities designed to boost rural tourism and rural areas at large. The prerequisites that need to be met coincide with the primary activities preceding those to support the development of rural tourism. That's why it is very important not to neglect any part of the value chain, and to identify the place tourism deserves in the chain.

The development of rural tourism as a segment of the value chain in agrarian cooperatives would have multiple effects on the rural areas in which the cooperatives operate, as it would integrate all the other activities more closely. Education programmes would support the collective members who have the potential and are interested in adding the tourist component to their work. Moreover, those already involved in rural tourism will be encouraged to improve the quality and expand the range of their services. 
To meet the requirements of rural tourism, the cooperative members need to create a surplus, which they would transform into the household's assortment of services. The surplus, created as the result of an increasing number of tourists, might motivate the collective members to improve their farm machinery by investing in new equipment. A successful member of the cooperative who has added rural tourism to his business can easily attract new members to the cooperative. The role of rural tourism is, therefore, to start the value chain and tighten the links between the primary and support activities within.

General managers of agrarian cooperatives play a key role in the value chain. It is their knowledge, skills and competence that can merge the potentials of the external surroundings with the needs of a cooperative and its members. Modern business conditions require a constant reconsideration of the purpose of existence and activity, which in the context of agrarian cooperatives involves a decision if a tourist business component is to be integrated into a collective or not, given the long-term development of rural areas.

\section{Methodology}

The area of research covered by the paper is the impact the opinions by agrarian cooperatives' general managers may have on opportunities to revitalise tourism through within the agrarian cooperative business.

The purpose of the paper is to analyse the opinions of the general managers of agrarian cooperatives, in order to find out if tourism can be included in their business portfolios.

The research sample includes 112 general managers of agrarian cooperatives that have the status of active business entities, and a positive financial result. The active businesses aside, the Business Registers Agency reports that an increasing number of agrarian cooperatives have been deleted from the register, entered bankruptcy proceedings or a liquidation process. The reason the authors decided to place an emphasis on the active business status and a positive financial result in the sampling procedure was the assumption that agrarian cooperatives operate in a market and have built the capacity for strategic development and growth.

The paper explores commitment by the general managers to use the organisational structure, human resources and business decisions to integrate rural tourism in the operation of agrarian cooperatives.

\section{Research Instrument}

The questionnaire consists of a set of 35 questions, of which 29 include a Likert-type five-point scale to rate the answers (1 - strongly disagree, 2 - disagree, 3 - neither agree nor disagree, 4 - agree, 5 - strongly agree). The remaining six questions offer positive and negative response options (yes or no).

Hypotheses: 
H1: The role of tourism in the operation of agrarian cooperatives should be expanded.

H2: General managers are not familiar enough with the effects of tourism on the agrarian cooperative business.

H3: Human resources constitute a serious obstacle to the operation of agrarian cooperatives and long-range business planning.

The research results have been statistically processed, based on recognised statistical methods. Descriptive statistics have been provided (the mode, median and standard deviation). The data processing involved the following statistical analyses:

- $\quad$ Sample Analysis - T test, ANOVA;

- Linear Correlation;

- $\quad$ Factor Analysis - Multivariate Analysis.

These methods have been selected to explain more accurately the problems arising from the revitalisation of rural tourism through the operation of agrarian cooperatives.

\section{Results}

Based on the argument that tourism should be revitalised as an area of business within the operation of agrarian cooperatives, a comparison has been made with categorial variables. The research results are presented in tables.

The T-Test showed that the general managers of agrarian cooperatives maintain different views as to strategic frameworks and guidelines:

Cooperative members' involvement in tourism $(\mathrm{t}=-0.66, \mathrm{df}=110, \mathrm{p} \leq 0.51)$. Since the significance level is greater than 0.05 , the conclusion is that the occurrences are not interrelated, proving the null hypothesis.

Defined vision and mission $(\mathrm{t}=3.69$, $\mathrm{df}=110$, $\mathrm{p} \leq 0.00)$. The statistical significance is considerable, as a $95 \%$ confidence level has been recorded. The general managers of the agrarian cooperatives that have defined their visions and missions are more positive towards the integration of tourism into the cooperatives' business trends.

$(\mathrm{t}=2.27, \mathrm{df}=110, \mathrm{p} \leq 0.03)$. Just like in the previous case, there is a statistically significant difference, and the null hypothesis is disproved. Namely, the general managers of agrarian cooperatives that have adopted a strategy on development believe that tourism should be integrated in the operation of the collectives.

- $\quad$ Cooperation with similar organisations abroad $(\mathrm{t}=2.79, \mathrm{df}=110, \mathrm{p} \leq 0.01)$. There is a statistically significant difference, which means that the general managers who have initiated cooperation with similar organisations abroad are more inclined to support the integration of tourism in the collectives' operations. 
- Using the experience of partner organisations abroad $(\mathrm{t}=2.66$, $\mathrm{df}=110, \mathrm{p}$ $\leq 0.01)$. In this case, too, there is a statistically significant difference, as $\mathrm{p} \leq 0.05$. The general managers of agrarian cooperatives applying the experience arising from cooperation with partner organisations tend to recognise the importance of tourism in the operation of agrarian cooperatives.

- $\quad$ Professional assistance in the revitalisation of tourism through the functioning of agrarian cooperatives $(t=2.42, d f=110, p \leq 0.02)$. A 95\% confidence level has been reached, meaning that variables are interrelated. The general managers of the agrarian cooperatives who feel they need professional assistance in the revitalisation of tourism are strong advocates of the idea to make tourism one of the activities of the agrarian cooperative.

Table 2. Differences in terms of strategic orientation and cooperation on the one hand, and the argument that tourism can be revitalised through the operation of agrarian cooperatives (Leven's and T-Tests used).

\begin{tabular}{|c|c|c|c|c|c|c|c|c|c|c|}
\hline \multirow{2}{*}{$\begin{array}{l}\text { Dependent } \\
\text { variable }\end{array}$} & \multicolumn{7}{|c|}{ Levene's test } & \multicolumn{3}{|c|}{ t-test } \\
\hline & $\mathrm{F}$ & Sig. & $\mathrm{t}$ & df & $\begin{array}{l}\text { Sig. } \\
\text { (2-tailed) }\end{array}$ & $\begin{array}{l}\text { Mean } \\
\text { Diff. }\end{array}$ & \begin{tabular}{|l} 
Std. \\
Error \\
Diff.
\end{tabular} & Mean & $\begin{array}{l}\text { Std. } \\
\text { Deviation }\end{array}$ & \begin{tabular}{|l} 
Std. \\
Error \\
Mean
\end{tabular} \\
\hline $\begin{array}{l}\text { Cooperative } \\
\text { members' } \\
\text { involvement in } \\
\text { tourism }\end{array}$ & 0,00 & 0,98 & $-0,66$ & 110,00 & 0,51 & $-0,12$ & 0,18 & 3,37 & 0,98 & 0,12 \\
\hline $\begin{array}{l}\text { Defined vision } \\
\text { and mission }\end{array}$ & 3,19 & 0,08 & 3,69 & 110,00 & 0,00 & 0,75 & 0,20 & 3,59 & 0,79 & 0,08 \\
\hline $\begin{array}{l}\text { Adopted } \\
\text { development } \\
\text { strategy }\end{array}$ & 1,34 & 0,25 & 2,27 & 110,00 & 0,03 & 0,40 & 0,18 & 3,61 & 0,81 & 0,11 \\
\hline \begin{tabular}{|l} 
Cooperation \\
with similar \\
organisations \\
abroad
\end{tabular} & 0,92 & 0,34 & 2,79 & 110,00 & 0,01 & 0,52 & 0,19 & 3,59 & 0,91 & 0,11 \\
\hline $\begin{array}{l}\text { Use of the } \\
\text { experience } \\
\text { of partner } \\
\text { organisations } \\
\text { abroad }\end{array}$ & 0,41 & 0,53 & 2,66 & 110,00 & 0,01 & 0,47 & 0,18 & 3,68 & 0,89 & 0,13 \\
\hline $\begin{array}{l}\text { Professional } \\
\text { assistance in the } \\
\text { revitalization } \\
\text { of tourism, } \\
\text { integration } \\
\text { into agrarian } \\
\text { cooperatives }\end{array}$ & 0,24 & 0,63 & 2,42 & 110,00 & 0,02 & 0,57 & 0,24 & 3,52 & 0,88 & 0,09 \\
\hline
\end{tabular}

Source: Author's own calculation 
A strategic orientation of agrarian cooperatives requires a pre-defined vision, mission and development strategy. The conclusion is that the general managers of agrarian cooperatives, committed to the key strategic frameworks, have recognised tourism as an important business activity in the operation of the cooperatives, confirming the hypothesis number one (H1).

Given that the Cooperatives Act has defined a framework within which a portfolio of different activities lies, the purpose of this paper is to find out to what degree business decisions have been designed to change the way agrarian cooperatives work today (Table 3).

Table 3. Correlation between arguments on the revitalisation of tourism and changes in the operation of agrarian cooperatives

\begin{tabular}{|l|l|lr|}
\hline \multicolumn{2}{|l|}{} & $\begin{array}{l}\text { Identification and revitalization of } \\
\text { other activities in the operation of } \\
\text { agrarian cooperatives }\end{array}$ \\
\hline $\begin{array}{l}\text { Unchanged operation of } \\
\text { cooperatives }\end{array}$ & Correlation Coefficient & &,$- 671^{* *}$ \\
\hline & Sig. (2-tailed) & & 112 \\
\hline & $\mathrm{N}$ & &, $293 * *$ \\
\hline $\begin{array}{l}\text { Revitalisation of tourism } \\
\text { cooperatives }\end{array}$ & Correlation Coefficient & 0,002 \\
\hline & Sig. (2-tailed) & 112 \\
\hline & $\mathrm{N}$ & & \\
\hline
\end{tabular}

Source: Author's own calculation

Note: $* *$. Correlation is significant at the 0.01 level (2-tailed).

The general managers of the agrarian cooperatives who believe that it's not necessary to change the existing structure of business operations, are largely unlikely to consider a business strategy designed to expand into new activities, which a statistically significant negative correlation has confirmed.

It is noteworthy that there is a statistically significant correlation between the argument of revitalisation of tourism as part of the operation of agrarian cooperatives, and the argument of identifying and revitalising other activities in the collectives. The general managers in favour of expanding into other activities, believe that tourism might be one of them.

The agrarian cooperatives that have failed to implement their strategies properly, or do not have one at all, will face different challenges in the market sooner or later. The definition and assessment of priorities can shape the cooperative business in the long run. The table below shows a correlation between the strategic, tactical and operative goals and the argument of tourism as an additional business activity in the operation of the collectives. 
Table 4. Correlation between pre-defined goals and the argument of tourism as a revitalised activity in the operation of cooperatives

\begin{tabular}{|c|c|c|}
\hline Item & & $\begin{array}{c}\text { Tourism as an additional activity in the } \\
\text { operation of a cooperative. }\end{array}$ \\
\hline \multirow{3}{*}{$\begin{array}{l}\text { Expansion of the } \\
\text { cooperative's business } \\
\text { activities }\end{array}$} & $\begin{array}{l}\text { Correlation } \\
\text { Coefficient }\end{array}$ &, $409 * *$ \\
\hline & Sig. (2-tailed) & 0 \\
\hline & $\mathrm{N}$ & 112 \\
\hline \multirow{3}{*}{ Software business } & \begin{tabular}{|l|} 
Correlation \\
Coefficient \\
\end{tabular} &, $408 * *$ \\
\hline & Sig. (2-tailed) & 0 \\
\hline & $\mathrm{N}$ & 112 \\
\hline \multirow{3}{*}{ Loan repayment } & $\begin{array}{l}\text { Correlation } \\
\text { Coefficient }\end{array}$ &,$- 188^{*}$ \\
\hline & Sig. (2-tailed) & 0,047 \\
\hline & $\mathrm{N}$ & 112 \\
\hline
\end{tabular}

Source: Author's own calculation

Note: **. Correlation is significant at the 0.01 level (2-tailed).

The general managers of the agrarian cooperatives who believe that it's necessary to expand into new activities confirm that tourism is one of them.

When it comes to software business, it is important to underline the affirmative position of the respondents on the integration of tourism. In other words, the respondents are familiar with the importance of information technologies in developing a business and gaining a competitive advantage. A statistically negative correlation has been noted between the argument of tourism and the repayment of loans as a strategic goal, leading to the conclusion that the respondents do not see tourism as an opportunity to find an easier way out of the financial crisis.

Based on factor analysis, (Extraction Method, Principal Component Analysis), three factors have been identified, as shown in the table below. Factor weights have been computed for every variable included in the analysis. The principal component analysis has been used to identify the factors. To test a correlation between the original variables, two statistical tests have been used: Bartlett's Test of Sphericity $(p=0.00)$ and Kaiser-Meyer-Olkin, which measured 0.75 .

Table 5. Matrix assembly

\begin{tabular}{|l|l|c|c|}
\hline \multirow{2}{*}{ Item } & \multicolumn{3}{c|}{ Factor } \\
\cline { 2 - 4 } & $\mathbf{1}$ & $\mathbf{2}$ & $\mathbf{3}$ \\
\hline Legislation & 0.784 & & \\
\hline Lack of government incentives & 0.725 & & \\
\hline Number of employees & 0.697 & & \\
\hline Unfair competition & 0.696 & & 0.364 \\
\hline Credit liability & 0.632 & & 0.328 \\
\hline
\end{tabular}




\begin{tabular}{|c|c|c|c|}
\hline Employee structure & 0.592 & 0.551 & \\
\hline Operation of collective alliances & 0.441 & & 0.338 \\
\hline Education of members and employees & & 0.767 & \\
\hline Employee inefficiency & & 0.717 & \\
\hline Marketing & & 0.648 & \\
\hline Business connection & & 0.612 & 0.454 \\
\hline Recapitalisation & & & 0.776 \\
\hline Distribution of cooperative profit & & & 0.775 \\
\hline Relations between cooperative members and subagents & 0.414 & & 0.67 \\
\hline
\end{tabular}

Source: Author's own calculation

Three factors have been identified, explaining $57 \%$ of variance, indicating a modest yet sufficient level of variance the paper has focused on. The factors have been isolated to simplify the presentation of the SPSS outputs.

Factor 1, explaining a total of $28 \%$ of variance, refers to the problems arising from the national legislation and the role of the state in the operation of agrarian cooperatives.

Table 6. Factor 1

\begin{tabular}{|l|r|}
\hline \multicolumn{1}{|c|}{ Item } & \multicolumn{2}{c|}{ Factor Weight } \\
\hline Lack of government incentives & 0.725 \\
\hline Number of employees & 0.697 \\
\hline Unfair competition & 0.696 \\
\hline Credit liability & 0.632 \\
\hline Employee structure & 0.592 \\
\hline Operation of cooperative alliances & 0.441 \\
\hline $\begin{array}{l}\text { Relationship between cooperative members and } \\
\text { subagents }\end{array}$ & 0.414 \\
\hline
\end{tabular}

Source: Author's own calculation

In the context of Factor 1, individual problems have been detected in relation to government actions and in terms of what a cooperative might expect from the state, including a lack of government incentives and unfair competition.

The problems arising from the competence and efficiency of employees in agrarian cooperatives have merged into the Factor 2.

Table 7. Factor 2

\begin{tabular}{|l|r|}
\hline \multicolumn{1}{|c|}{ Item } & \multicolumn{1}{|c|}{ Factor weight } \\
\hline Education of cooperative members and employees & 0.767 \\
\hline Inefficiency of employees & 0.717 \\
\hline Marketing & 0.648 \\
\hline Business connections & 0.612 \\
\hline Employee structure & 0.551 \\
\hline
\end{tabular}

Source: Author's own calculation 
Factor 2 explains close to $17 \%$ of variance, dominated by the problems related to prospects for the employees and their competences. .

Factor 3 comprises a set of financial challenges affecting the operation and long-term activities of agrarian cooperatives.

Table 8. Factor3

\begin{tabular}{|l|r|}
\hline \multicolumn{1}{|c|}{ Item } & \multicolumn{1}{c|}{ Factor weight } \\
\hline Business connections & 0.454 \\
\hline Recapitalisation & 0.776 \\
\hline Distribution of cooperative profit & 0.775 \\
\hline Relations between cooperative members and subagents & 0.670 \\
\hline Unfair competition & 0.364 \\
\hline Credit liability & 0.328 \\
\hline Operation of cooperative alliances & 0.338 \\
\hline
\end{tabular}

Source: Author's own calculation

The last factor explains nearly $11 \%$ of variance, including mostly financial problems, like recapitalisation, profit distribution methods and the like.

A cross-reference between the three factors and the argument that tourism should be integrated in the operation of agrarian cooperatives unveiled a considerable correlation with Factor 2, as presented in the table below:

Table 9. Correlation between the Factors and the argument that tourism should be revitalised and integrated in the operation of the cooperatives

\begin{tabular}{|c|c|c|c|c|c|}
\hline Item & & \begin{tabular}{|l|} 
Tourism as \\
a revitalised \\
activity \\
in the \\
operation \\
of a \\
cooperative
\end{tabular} & $\begin{array}{l}\text { REGR } \\
\text { factor } \\
\text { score } \\
1 \text { for } \\
\text { analysis } \\
3\end{array}$ & $\begin{array}{l}\text { REGR } \\
\text { factor } \\
\text { score } \\
2 \text { for } \\
\text { analysis } \\
3\end{array}$ & $\begin{array}{l}\text { REGR } \\
\text { factor } \\
\text { score } \\
3 \text { for } \\
\text { analysis } 3\end{array}$ \\
\hline \multirow{3}{*}{$\begin{array}{l}\text { Tourism as a revitalised } \\
\text { activity in the operation } \\
\text { of a cooperative }\end{array}$} & Corr. Coeff & 1 &,$- 187 *$ & ,295** & 0.141 \\
\hline & Sig. (2-tailed) & & 0.049 & 0.002 & 0.139 \\
\hline & $\mathrm{N}$ & 112 & 112 & 112 & 112 \\
\hline \multirow{3}{*}{$\begin{array}{l}\text { REGR factor score } 1 \text { for } \\
\text { analysis } 3\end{array}$} & Corr Coeff. &,$- 187 *$ & 1 & 0.026 & 0.011 \\
\hline & Sig. (2-tailed) & 0.049 & & 0.786 & 0.912 \\
\hline & $\mathrm{N}$ & 112 & 112 & 112 & 112 \\
\hline \multirow{3}{*}{$\begin{array}{l}\text { REGR factor score } 2 \text { for } \\
\text { analysis } 3\end{array}$} & Corr. Coeff. & ,295** & 0.026 & 1 & 0.037 \\
\hline & Sig. (2-tailed) & 0.002 & 0.786 & & 0.695 \\
\hline & $\mathrm{N}$ & 112 & 112 & 112 & 112 \\
\hline \multirow{3}{*}{$\begin{array}{l}\text { REGR factor score } 3 \text { for } \\
\text { analysis } 3\end{array}$} & Corr. Coeff. & 0.141 & 0.011 & 0.037 & 1 \\
\hline & Sig. (2-tailed) & 0.139 & 0.912 & 0.695 & \\
\hline & $\mathrm{N}$ & 112 & 112 & 112 & 112 \\
\hline
\end{tabular}

Source: Author's own calculation

Note: **. Correlation is significant at the 0.01 level (2-tailed). 
The general managers who tend to believe that tourism should be a significant activity in the operation of a cooperative are also aware that the problems in the operation of the collective lie in the domain of human resources, confirming the hypothesis that human resources create major obstacles to the operation of agrarian cooperatives and long-term planning.

\section{Discussion}

A model for the operation of agrarian cooperatives in a modern business setting requires a completely new approach, based on a radical reconsideration of their operations and functions. The surroundings, external surroundings in particular, demand quick adaptation to change, which remains a serious challenge for Serbia's agrarian collectives.

The results of the research have confirmed that value creation has to be based on new sources, included timely in gaining a competitive advantage. The general managers of agrarian collectives prefer different strategies, and are separated into two groups - the re-activists, not involved in strategic planning, and the pro-activists, who have made their strategic orientation a priority.

The pro-activists have a certain vision, mission and development strategy, and are more likely to recognise the importance of tourism in the operation of agrarian cooperatives. On the other hand, the re-activists have no vision, mission and development strategy, and are quite unlikely to change the status of their cooperatives any time soon.

The lack of planning documents with a number of agrarian collectives should be viewed as a source of instability and unsystematic business decisions that can't be consistent with the cooperative's goals, as there aren't any. With those possessing the planning documents, there should be firm insistence that the goals be met, and any deviation evaluated.

The general managers of agrarian cooperatives initiating cooperation with similar organisations have also used the experience arising from the collaboration. This is very important as the general managers are striving to identify a concept acceptable for the existing organisation structure, corresponding with the capacity of their cooperative, and conductive to the use of the new experience. The research results show that they are open to the integration of tourism, and are quite confident about multiplicative effects tourism might have on economy.

The results of the research have also unveiled clear interest in expanding into new activities. It goes without saying that tourism can be one of them, given it heterogeneous nature. The initiation of tourism into the operation of a cooperative may raise the issue of the performance of other activities, constituting the pillars of the collective business.

Modern business implies an integral approach to management, based on information technologies. Research shows that the general managers of cooperatives in favour of the integration of tourism into their operation attach more importance to software business, and see it as part of a solution to their problems. The results make it clear that software owned by an agrarian cooperative facilitates its operations, unifying the business processes from the procurement of raw materials, through accounting to creating financial reports. 
Even though a group of the general managers of agrarian corporations are clearly proactive, their enthusiasm is often curbed by factors in the external surroundings, including, above all, restrictions in the national legislation and the ambivalence of the state as to the fundamental criteria to define a business setting for the collectives. There's a clear lack of appropriate government incentives to facilitate the procurement of raw materials, machinery, etc.

The European Union (EU) has provided for a more transparent system of incentives, making the end-product competitive and in line with the standards of quality (Pejanovic et al, 2016; Mataga et al, 2013).The EU model is quite different from Serbia's though, the latter offering a subsidizing model that can hardly meet the needs of the cooperatives (Ševarlić, Nikolić, 2012). The research results have confirmed the problem of subsidies, which cannot remove the fundamental barriers to a viable operation of the collectives, but address operative problems only.

In order to achieve the goals corresponding with the cooperative's vision and mission, it is necessary that the employees possess certain knowledge and skills. The results show, however, that there's pronounced incompetence in human resources, lacking potential to meet the new market demands, in this case, the inclusion of tourism into the operation of the cooperatives. The general managers are completely aware of the limitations, and are prepared to educate the staff.

In the era of knowledge economy, the definition of intellectual capital, which involves the knowledge, skills, experience and creativity of the employees, goes beyond traditional interpretations of capital, which is why it deserves special attention from the general managers.

The results confirmed the dominance of financial problems in the functioning of the cooperatives, but they are a mere consequence of the problems arising from the incompetence of cooperatives' employees, poor infrastructure and the requirements of doing business. A group of the general managers agreed that tourism can be the driving force behind initiating re-engineering as a strategic management concept. Neither the role of the state nor finances are as much of the problem for those who feel that tourism can be a new activity as the organisation structure, skills, education and efficiency of the employees are.

\section{Conclusion}

Research papers have confirmed that agrarian cooperatives have been facing a series of structural problems that have curbed their growth and development, including restrictive legislation, market instability and the questionable competiveness of agricultural products (Simonović, 2014; Pejanović, Njegovan, 2011; Paraušić, Cvijanović, 2014).

The survey involving the general managers of agrarian cooperatives produced a general conclusion that they were quite positive towards the revitalisation of tourism and its initiation into the cooperatives, which confirmed the first hypothesis. The research 
results have also showed that a dominant positive stance on tourism goes hand in hand with their increasing awareness of multiplicative effects of tourism on the economic trends in rural areas, disproving the hypothesis number two.

On the other hand, a move to revitalise tourism and integrate it into the operation of agrarian cooperatives may be a serious challenge, as the general managers of the cooperatives have cautioned that human resources and the incompetence of employees might be a stumbling block in the process, proving the third hypothesis. It is safe to say that the direction in which the cooperatives should develop has been established, but that it calls for re-engineering as a strategic management concept, in order to create conditions for a competitive business activity.

The limitations of this paper include an under-researched sample and the circumstances surrounding the study, including the transition of the cooperative sector.

The research presented in this paper sheds new light on just one of many approaches to the management of agrarian cooperatives, and their potential to reconsider their operations and analyse many other factors and circumstances involving in making timely business choices.

The positions of the general managers of agrarian cooperatives have been researched repeatedly over the past few years. One of the key reasons for the growing interest is that the general managers, integrated in the management structure, are the generators of change and new values in their organisations. Fully aware of the limitations of the study and a specific social and economic national context, we believe it is important to continue the research to pave the way to a proper setting for the next strategic steps in the cooperative sector and agriculture in general. The Republic of Serbia's clear commitment to joining the EU makes the theme all the more relevant.

\section{Literature}

1. Cai, R., Ma, W., Su, Y. (2016): Effects of member size and selective incentives of agricultural cooperatives on product quality. British Food Journal Vol. 118, no. 4 , pp. $858-870$.

2. Đekić, S. (2005): Agrarni menadžment (978-86-85099-96-0). Ekonomski fakultet u Nišu, Niš.

3. Đoković, F., Kulović, Dž. (2013): Strategijsko odlučivanje u hotelijerstvu, Socioeconomica. Vol.2, No.4, pp. 288 - 300.

4. Harris, A., Fulton, M. (1999): Farm machinery cooperation in Saskatchewan and Quebec. Centre for Cooperatives, University of Saskatchewan, Saskatoon.

5. Krstić, V. (2002): Neke prednosti zadružnog organizovanja u našim uslovima privređivanja. Ekonomika, Vol. 48, No 4-5, pp 106-110.

6. Li, Z., Jacobs, K., Artz, G. (2015) The cooperative capital constraint revisited. Agricultural Finance Review, Vol. 75, No. 2, pp. 253 - 266. 
7. Maričić, B. (2006): Zadrugarstvo u vremenu tranzicije: neostvarene incijative(86-84153-65-0). Naučna KMD, Beograd.

8. Marković, Ž. (2013): Putevi i stranputice Srbije: samoupravljanje, tranzicija, zadrugarstvo (978-86-6021-069-4). Naučna KMD, Beograd.

9. Mataga, Ž., Papeš, D., Petak, A. (2009): Poljoprivredne zadruge u zemljama Europske Unije, Sociologija i prostor: časopis za istraživanje prostornoga i sociokulturnog razvitka, Vol.43, No.1, pp. 215-277.

10. Mihailović, L., Pejčić, H., Marković, K. (2005): Zemljoradničko zadrugarstvo između teorije i prakse. Sven, Niš.

11. Mihailović, L. (1998): Neki savremeni pogledi na zadrugarstvo i ruralni razvoj. Ekonomika poljoprivrede, Vol. 45, No. 1-2, pp 23-34.

12. Mwesiumo, D., Halpern, N. (2016): Interfirm conflicts in tourism value chains, Tourism Review, Vol. 71, No. 4, pp. 259 - 271.

13. Njegovan, Z. (2011): Agrarno ili zadružno pitanje - prilog za razumevanje zadrugarstva u Republici Srbiji. Ekonomika preduzeća, Vol. 59, No. 5-6, pp 297-307.

14. Njegovan, Z., Pejanović, R. (2009): Ruralna regionalizacija Vojvodine (97886-7728-075-8). Poljoprivredni fakultet Univerziteta u Novom Sadu, Novi Sad.

15. Paraušić, V., Cvijanović, D. (2014): Kokurentnost agroprivrede Srbije - klasteri u funkciji održive regionalne konkurentnosti (978-86-6269-034-0). Institut za ekonomiku poljoprivrede, Beograd.

16. Pejanović, R. (2005): Agrarne zadruge kao preduzetničke organizacije, Ekonomski vidici, Društvo ekonomista Beograda,Vol. 10, No. 1, pp. 45-55.

17. Pejanović, R. (2015): Predgovor za knjigu: Zadrugarstvo u Srbiji, Hesperia, Beograd, str. $9-12$.

18. Pejanović, R., Glavaš-Trbić, D., Tomaš-Simin, M. (2013): O uzrocima krize poljoprivrede Republike Srbije. Ekonomika poljoprivrede, Vol. 60, No. 2, pp. 253-264.

19. Pejanović, R., Njegovan, Z. (2011): Ruralni razvoj i lokalno-ekonomski razvoj AP Vojvodine. Poljoprivredni fakultet Univerziteta u Novom Sadu, Novi Sad., pp 115-132.

20. Pejčić, H. (2011): Ekonomika poljoprivrede (978-86-7746-277-2). $4^{\text {th }}$ ed., Sven, Niš.

21. Pejnović, D., Radeljak Kaufmann, P., Lukić, A. (2016): Development and Contemporary Characteristics of Agricultural Cooperatives in the Area of Croatia. Hrvatski geografski glasnik, Vol. 78, No. 2, pp. 5-48.

22. Porter, M. (1998): On Competition (0-684-84146-0). Harvard Business School Press, Harvard. 
23. Richards, T., Manfredo, M. (2003): Post-merger performance of agricultural cooperatives. Agricultural Finance Review, Vol. 63, No. 2, pp. 175 - 192.

24. Simonović, Z. (2014): Upravljanje agrarom Srbije u tranziciji (978-86-6269037-1). Institut za ekonomiku poljoprivrede, Beograd.

25. Ševarlić, M., Nikolić, M. (2012): Stavovi direktora zadruga i zadrugara o zemljoradničkom zadrugarstvu u Srbiji (978-86-86087-32-4). Društvo agrarnih ekonomista Srbije, Beograd.

26. Vučković, M. (1957): Zadrugarstvo. Zadružna štampa, Zagreb.

27. Y1lmaz, Z., Bititci, U. (2006): Performance measurement in tourism: a value chain model, International Journal of Contemporary Hospitality Management, Vol. 18, No. 4, pp. 341 - 349.

28. Zakon o zadrugama ("Official Gazette of the RS" no. 112/2015). 


\title{
MOGUĆNOSTI REVITALIZACIJE RURALNOG TURIZMA U FUNKCIONISANJU AGRARNIH ZADRUGA
}

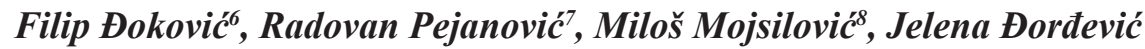 Boljanovic ${ }^{9}$, Katarina Plećic ${ }^{10}$}

\begin{abstract}
Rezime
Agrarne zadruge se nalaze još uvek u tranzicionom periodu. Dosadašnja praksa je pokazala da je potrebno preispitati delatnosti koje u njima funkcionišu. Prema Zakonu o zadrugama iz 2015. godine, ruralni turizam je prepoznat kao delatnost ali se u praksi to u većoj meri nije ispunilo. Kako bi se utvrdilo u kojoj meri postoje mogućnosti za revitalizaciju ruralnog turizma, sprovedenoje istraživanje među direktorima agrarnih zadruga. Analizirani su stavovi direktora u pogledu njihovog znanja o efektima ruralnog turizma na ruralna područja kroz delovanje zadruga i mogućnostima ljudskih resursa za sprovođenje organizacionih promena izazvanim revitalizacijom turizma. Takođe, analizirani su potencijali agrarnih zadruga u kontekstu eksternog okruženja. Rezultati istraživanja su pokazali da su direktori pozitivno ocenili revitalizaciju ruralnog turizma u poslovanju zadruga i da znaju za povoljne efekte turizma na ruralna područja, ali da je za realizaciju tih aktivnosti prepreka nekompetentnost zaposlenih u zadrugama.
\end{abstract}

Ključne reči: agrarne zadruge, ruralni turizam, direktori zadruga, revitalizacija.

6 Docent, dr Fillip Đoković, Univerzitet Singidunum, Fakultet zdravstvenih, pavnih i poslovnih studija, Železnička ulica br. 5, Telefon: +381 14292 610, E-mail: fdjokovic@singidunum.ac.rs

7 Redovni profesor, dr Radovan Pejanović, Univerzitet u Novom Sadu, Poljoprivredni fakultet, Ulica Dositeja Obradovica br. 8, 21000 Novi Sad, Telefon: +381 216350622 , E-mail: pejanovic@uns.ac.rs

8 Miloš Mojsilović, M.A., Ipsos Strategic Marketing, Ulica Gavrila Principa br. 8, Telefon: +381 11 3284 075, E-mail: mojsilovic.milos@gmail.com

9 Vanredni profesor, dr Jelena Đorđević Boljanović, Univerzitet Singidunum, Poslovni fakultet, Kumodraška ulica br. 261a, Telefon: +381 113094 094, E-mail: jboljanovic@singidunum.ac.rs

10 Katarina Plećić M.A., doktorant turizma, Univerzitet Singidunum, Fakultet zdravstvenih, pavnih i poslovnih studija, Železnička ulica br. 5, Telefon: +381 14292 610: +381 14292 610, E-mail: kplecic@singidunum.ac.rs 